\title{
GENETIC STRUCTURE OF NINE HORSE POPULATIONS
}

\author{
M. Burócziová, J. Říha, R. Židek, J. Trandžík, D. Jakabová
}

Received: December 13, 2007

\begin{abstract}
BURÓCZIOVÁ, M., ŘÍHA, J., ŽIDEK, R., TRANDŽÍK, J., JAKABOVÁ, D.: Genetic structure of nine horse populations. Acta univ. agric. et silvic. Mendel. Brun., 2008, LVI, No. 2, pp. 57-60

In the present study was estimate the genetic diversity and relationships among nine horses breeds in Czech and Slovak Republic.

In conclusion, the main objective of study was to show the level of genetic distance among the horse breeds with different history of breeding of each country. Furthermore, it should be clarified whether these populations and subpopulations are distinct enough from each other to justify defining separate breeds. This research concerns the variability of microsatellite markers in genotypes of horse. We compared the genetic diversity and distance among nine horse breeds Czech and Slovak Warmblood both of Czech origin, Slovak Warmblood of Slovak origin, Hucul, Hafling, Furioso, Noriker, Silesian Noriker and Bohemian-Moravian Belgian Horse.

In total, 932 animals were genotyped for 17 microsatellites markers (AHT4, AHT5, ASB2, HMS3, HMS6, HMS7, HTG4, HTG10, VHL20, HTG6, HMS2, HTG7, ASB17, ASB23, CA425, HMS1, LEX3) recommended by the International Society of Animal Genetics.

In the different population size, the allele frequencies, observed and expected heterozygosity, test for deviations from Hardy-Weinberg equilibrium and Polymorphism information content have been calculated for each breed. We analyzed genetic distance and diversity among them on the base of the dataset of highly polymorphic set of microsatellites representing all autozomes using set of PowerMarker v3.25 analysis tools and Structure 2.2. programme for results comparison.
\end{abstract}

microsatellite, horse breeds, genetic diversity

Introduct on genetic characterization is important to guard breed integrity and conserve breed identity. Furthermore, it is a prerequisite for managing genetic resources (Bjørnstad \& Røed, 2002). Molecular techniques have been widely used to analyse phylogenetic relationships among various animal groups and different breeds. Microsatellite loci comprise an attractive potential resource to determine population histories and evolutionary processes, as these loci permit simple and accurate typing in combination with high levels of polymorphism and widespread distribution in the genome. The usefulness of microsatellite markers has been documented in many previous equine population genetic studies (e.g. Cañon et al. 2000; Bjørnstad \& Røed, 2001; Cunningham et al. 2001). The present study is focused on using microsatellite markers to characterise genetic structure of horse populations in Czech Republic and Slovak Republic.

\section{MATERIAL AND METHODS}

Hair, blood and sperm samples were collected from 932 unrelated individuals of Czech Warmblood, Slovak Warmblood, Slovak Warmblood origin from Slovakia, Hucul, Hafling, Furioso, Noriker, Silesian Noriker and Bohemian-Moravian Belgian Horse. Genomic DNA was isolated using the JETQUICK Tissue DNA Spin Kit and JETQUICK Blood \& Cell Culture DNA Spin Kit (Genomed GmbH, Germany), by following the Protocol Handbook. Determination of microsatellites was performed using the PCR reaction with 17-plex horse genotyping kit designed by Applied Biosystems StockMarks ${ }^{\circledR}$ (Applied Biosystems, Foster City, CA, USA). The genotyping of microsatellite markers was performed on ABI PRISM 310 Genetic Analyzer (Applied Biosystems, Foster City, CA, USA) by fluorescent fragment analysis and detected by software GeneScan ${ }^{\circledR} 3.7$ NT. 
Alleles were asigned by GENOTYPER. Alleles were assingned to alphabetical symbols (B, C, F, G, H, I, J, K, L, M, N, O, P, Q, R, S). Genetic variability of each horse breeds was calculated as number of alleles $\left(\mathrm{N}_{\mathrm{A}}\right)$ per microsatellite, observed heterozygosity $\left(\mathrm{H}_{\mathrm{o}}\right)$, expected heterozygosity $\left(\mathrm{H}_{\mathrm{E}}\right)$, Polymorphism information content (PIC) under Hardy-Weinberg equilibrium (Table I). PowerMarker v 3.25. was used for noted analysis. Nei's standard distance was measured for graphs construction using PhyloDraw V0.82 programme and Structure 2.2 programme for figure construction using clusterisation and classification methods.

The breeds were divided into two subgroups warmbloods (Czech Warmblood, Slovak Warmblood, Slovak Warmblood origin from Slovakia, Hucul, Furioso) and coldbloods (Noriker, Silesian Noriker Bohemian-Moravian Belgian horse, Hafling).

\section{RESULTS}

The total number of alleles was 168 across the 17 microsatellites. The number of alleles per locus ranged from 6 (HMS6) to 15 (ASB17). In the data set of all individuals, the average number of alleles was 7.150. The average observed heterozygosity of warmblood horses ranged from 0.716 (Czech Warmblood) to 0.947 (Furioso), in the coldblood populations varied from 0.711 (Bohemian-Moravian Belgian Horse) to 0.781 (Table I). Gene diversity

$\left(\mathrm{H}_{\mathrm{e}}\right)$ varied in warmblood horses from 0.748 (Hucul) to 0.777 (Slovak Warmblood origin from Slovakia) and coldblood breeds from 0.686 (Hafling) to 0.722 (Noriker). The Polymorphism information content PIC ranged from 0.641 (Hafling) to 0.743 (Slovak Warmblood origin from Slovakia).

I: Average number of alleles per locus, Heterozygosity $H_{0}$ - observed. $H_{e}$ - expected heterozygosity, Average polymorphism information content PIC

\begin{tabular}{|l|c|c|c|c|c|}
\hline \multicolumn{1}{|c|}{ Breed } & $\begin{array}{c}\text { Number of } \\
\text { Animals in } \\
\text { Breed }\end{array}$ & $\begin{array}{c}\text { Average no. of } \\
\text { alleles } \\
\text { per locus }\end{array}$ & $\mathrm{H}_{\mathrm{o}}$ & $\mathrm{H}_{\mathrm{e}}$ & PIC \\
\hline Czech Warmblood (CW) & 234 & 8.294 & 0.716 & 0.759 & 0.724 \\
\hline Slovak Warmblood (SW) & 234 & 7.882 & 0.730 & 0.750 & 0.710 \\
\hline Slovak Warmblood origin from Slovakia (SWSR) & 96 & 8.058 & 0.921 & 0.777 & 0.743 \\
\hline Hucul (HUC) & 124 & 8.235 & 0.757 & 0.748 & 0.716 \\
\hline Furioso (FUR) & 37 & 6.059 & 0.947 & 0.755 & 0.721 \\
\hline Hafling (HFLG) & 105 & 6.647 & 0.781 & 0.686 & 0.641 \\
\hline Noriker (NOR) & 44 & 6.706 & 0.741 & 0.722 & 0.682 \\
\hline Silesian Noriker (SLN) & 22 & 5.823 & 0.744 & 0.707 & 0.664 \\
\hline Bohemian-Moravian Belgian Horse (BMBH) & 35 & 6.647 & 0.711 & 0.716 & 0.681 \\
\hline
\end{tabular}

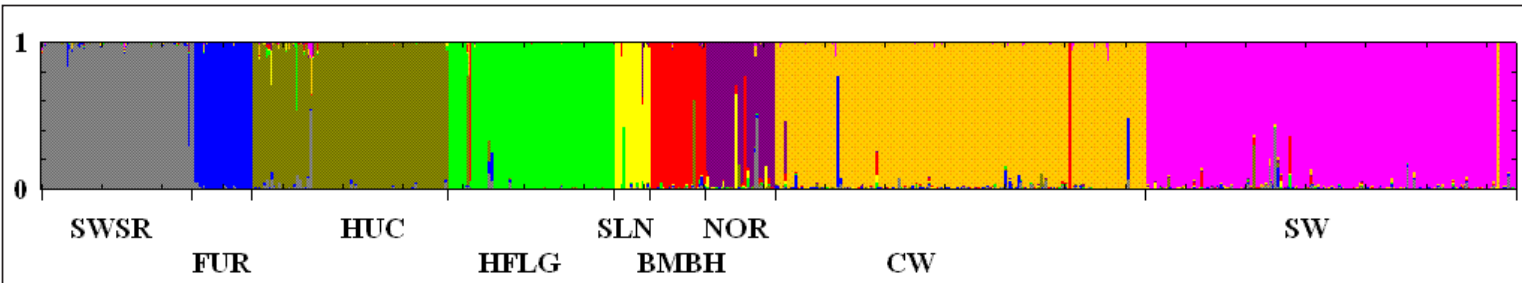

\begin{tabular}{l|l|l|l|l|l|l|l|l|} 
SW & CW & NOR & BMBH & SLN & HFLG & HUC & FUR & SWSR
\end{tabular}

1: The diversity and population structure of nine horse breeds using Structure 2.2. programme. Each individual is represented by one thin vertical line and each breed is characterized by one colour. 


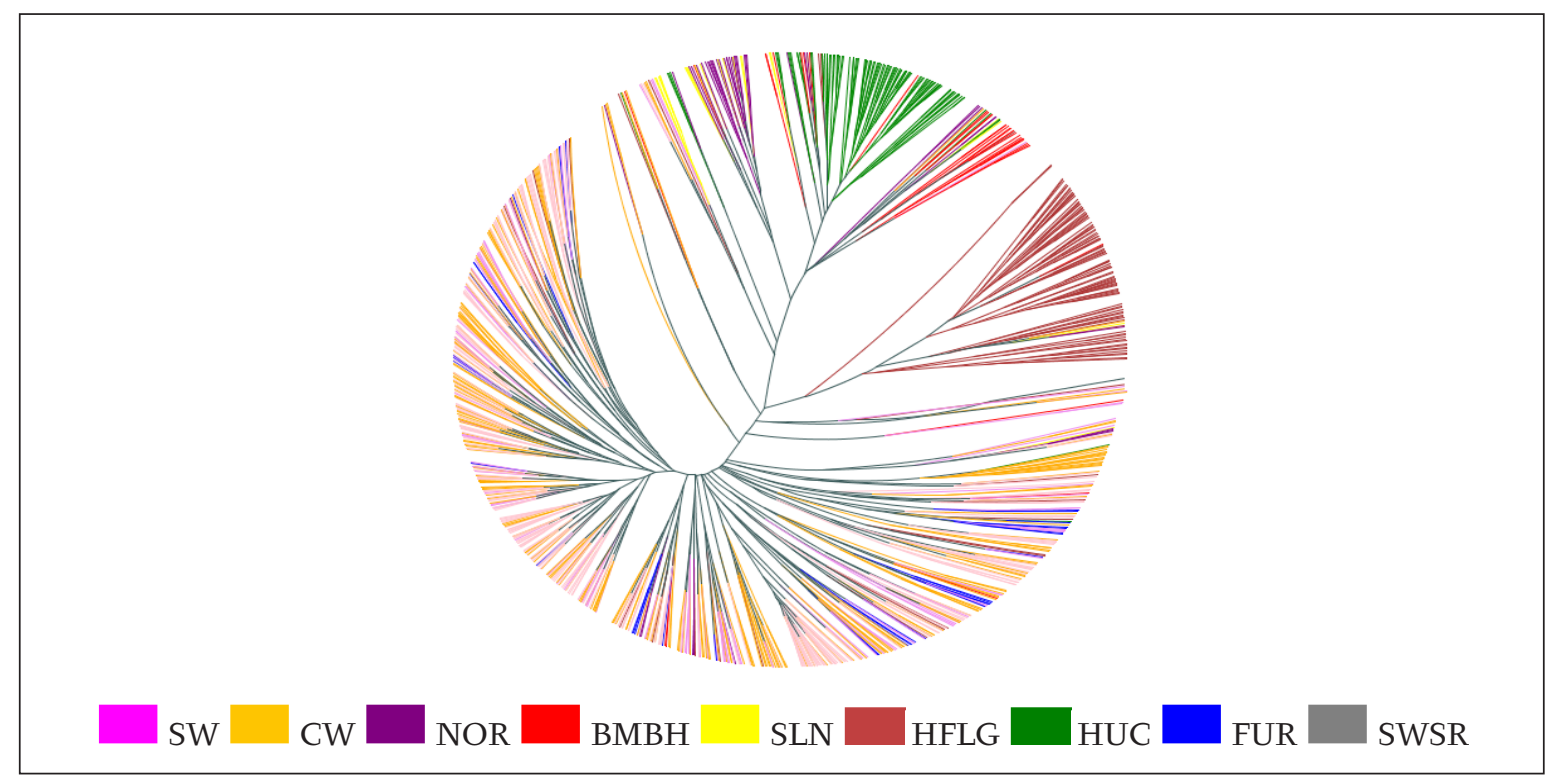

2: The UPGMA dendograms was construced from Nei's standard genetic distance (1972), summarizing genetic distance among 932 horses based on 17 microsatellites.

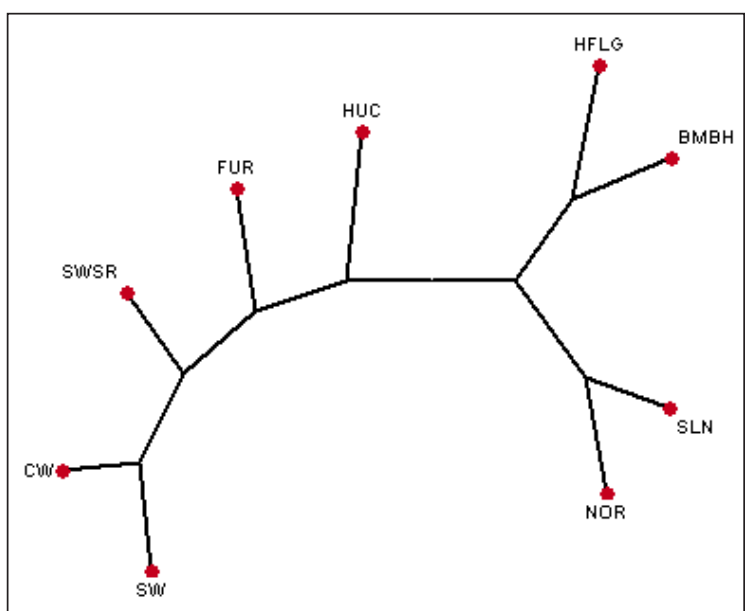

3: The neighbour-joining trees was construced from Nei's standard genetic distance (1972) mine horse populations.

\section{DISCUSSION}

The Bayesian approach detects not only population structures by the identification of clusters, but also allows a probabilistic estimate of the proportion with which an individual belongs to one of the inffered clusters (Glowatzki-Mullis et al., 2005).
However, a many andmixtures of different memberships were found in breeds. Hafling horses had partial membership with Bohemian-Moravian Belgian Horse what was unexcepted result.We identified a potential outbreeding in these two breeds as a result of deficient pedigree verification or non correct purebreeding. The Czech Warmblood, Slovak Warmblood, Slovak Warmblood origin from Slovakia and Furioso clustered together. Warmblood horses in Czech and Slovak Republic are formed from local breeds with high introgression of European Warmblood, in Czech Republic is unbalanced mating and in Slovakia is mating based on the Furiosso breed (Fig. 1). Fig. 1,2 shows high similarity among Czech Warmblood, Slovak Warmblood, Slovak Warmblood origin from Slovakia and Furioso populations because of opened populations for a number of generations and similar history of breeding programs. Another possible reason of high diversity is a small effort for breeding programe in these populations. Fig. 2 shows the Hucul breed is the most homogenous from all of the breeds, as we expected. The Hucul stud book is considered as closed, pureblooded breeding is using strictly pure lines of Hucul breed.

\section{SÚHRN}

Genetická struktúra deviatich plemien koní

Plemená boli anlyzované vybranými 17 mikrosatelitnými markermi (AHT4, AHT5, ASB2, HMS3, HMS6, HMS7, HTG4, HTG10, VHL20, HTG6, HMS2, HTG7, ASB17, ASB23, CA425, HMS1, LEX3). Genotypové dáta 17 mikrosatelitných markerov sa získali pomocou DNA analýzy biologických vzoriek vybraných jedincov. Panel testovaných mikrosatelitných markerov je doporučený organizáciou FAO pre štúdium genetickej diverzity, organizáciou ISAG pre overovanie paternity. 
Na základe genetickej diverzity sa zaoberáme otázkami oddelenia populácie Českého teplokrvníka, Slovenského teplokrvníka a Slovenského teplokrvníka chovaného na Slovensku, a vytvorenia geneticky rozdielných skupín jedincov a či je možné na základe týchto údajov vybrané plemená dostatočne charakterizovat' a vymedzit'.

Aj napriek skutočnosti, že plemená Český a Slovenský teplokrvník majú oddelené plemenné knihy, stanovené genetické vzdialenosti, výsledky klasifikačných i zhlukovacích metód ukazujú, že plemená nie je možné na základe nami sledovaných mikrosatelitných markerov uspokojivo vymedzit'. V rámci skupiny Český teplokrvník neboli zahrnuté jedince plemien Moravský teplokrvník a kôn Kinský, ktoré v minulosti boli súčastou plemena Český teplokrvník.

Pri analýze genetickej charakteristiky plemena Hucul sa zistila vysoká miera genetickej variability, napriek tomu, že stav tohto plemena v rámci ČR i celosvetovo varovný, je zrejmé, že i pri zostávajúcom stave jedincov je možné zachovat genetickú variabilitu a odlišnost' v porovnaní s ostatnými plemenami koní, čo sa chovatel'om doposial' darí. Sledovanie genetickej diverzity plemena môže výrazne prispiet' k jeho zachovaniu.

Algoritmy pre úlohy klasifikácie, zhlukovania a faktorovú analýzu použité v práci sa ukázali vhodné pre štúdium genetickej diverzity, štruktúry populácií na rôznych úrovniach a rozlíšenie plemien.

mikrosatelity, plemena koní, genetická diverzita

\section{SUMMARY}

The breeds were analysed for 17 microsatellite markers (AHT4, AHT5, ASB2, HMS3, HMS6, HMS7, HTG4, HTG10, VHL20, HTG6, HMS2, HTG7, ASB17, ASB23, CA425, HMS1, LEX3). These sets of microsaltellites are included in the list recommended by FAO for diversity studies and ISAG for parentage verification. The genetic distances and clusterisation method between Czech Warmblood and Slovak Warmblood based on microsatellite markers clearly showed that there is no evidence of two populations although they have separate studbooks. There should be higher effort of selection, efficient breeding strategies, implemented breed studboods and controlled genetic exchange crossings with other breeds. The Slovak Warmblood origin from Slovakia has a high influence of Furioso as a result of breeding plans in the Slovak national stud farms.

The Hucul appeared as the most divergent breed among all nine breeds. The reason could be the reproduction isolation, genetic drift, absence of migration and genetic bottleneck.

Investigation of genetic variations and the pedigree of this population will be neccessary.

Clusterisation, classification methods we selected for genetic diversity and population structure tasks appeared usable for obtain negotiable results. Especially, multinominal methods based on machine learning and principles of artificial intelligence seem to have a good performance for our purposes including breed discrimination.

This work was supported by grant FRVS FR270251.

\section{REFERENCES}

BJORNSTAD, G., and ROED, K. H., 2002: Evaluation of factors affecting individual assignement precision using microsatellite data from horse breeds and simulated breed crosses. Animal Genetics 33: 264.

CAÑON, J., CHECA, M. L, CARLEOS, C., VEGAPLA, L.,VALLEJO, M. and DUNNER, S., 2000: The genetic structure of Spanish Celtic horse breeds inferred from microsatellite data. Animal Genetics 31: 39.
CUNNINGHAM, E. P., DOOLEY, J. J., SPLAN R. K. and BRADLEY, D. G., 2001: Microsatellite diversity, pedigree relatedness and the contributions of founder lineages to thoroughbred horses. Animal Genetics 32: 360.

GLOWATZKI-MULLIS, M. L., MUNTWYLER, J., PFISTER, W., MARTI, E., RIEDER, S., PONCET, P. A. and GAILLARD, C.,2006: Genetic diversity among horse populations with a special focus on the Franches-Montagnes breed. Animal Genetics 37: 33. 